Studia Judaica 19 (2016), nr 2 (38), s. 275-299

doi:10.4467/24500100STJ.16.013.6224

Jerzy Kroczak

\title{
Żydzi w Nowych Atenach Benedykta Chmielowskiego
}

\author{
JEWS IN NEW ATHENS BY BENEDYKT CHMIELOWSKI
}

\begin{abstract}
Benedykt Chmielowski (1700-1763), a Catholic priest, the author of the New Athens encyclopaedia (extended edition: Lwów 1754-1756) included in his polyhistorical work plenty of information on issues related to Jews. The article discusses these issues and connects their specificity with the character of different parts of the work in which Chmielowski placed them as well as with the detected and secret sources of his knowledge about Jews (especially books by Early Modern scholars) and the ways he dealt with those sources. The author of the article also shows Chmielowski's writing strategies, placing New Athens in the tradition of baroque encyclopaedism - a literary production typical of the previous epoch.
\end{abstract}

Keywords: encyclopaedism, New Athens, Benedykt Chmielowski.

Słowa kluczowe: encyklopedyzm, Nowe Ateny, Benedykt Chmielowski.

Benedykt Chmielowski (a właściwie: Joachim Benedykt Chmielowski, 1700-1763) znany jest przede wszystkim jako autor Nowych Aten ${ }^{1}$, których dwa tomy wydane zostały w latach 1745-1746 we Lwowie, gdzie też wkrótce - w latach 1754-1756 - wydrukowano czterotomową, poszerzoną wersję tego dzieła ${ }^{2}$. Autor realizował w nim model barokowego polihistoryzmu: starał się zgłębić wszelkie dziedziny wiedzy, by poddać

${ }^{1}$ Cytaty i lokalizacje w niniejszym artykule odnoszą się do wydania drugiego Nowych Aten - liczba rzymska oznacza tom, liczba arabska - stronę.

${ }^{2}$ Publikacje na temat Nowych Aten są liczne, a opinie - różnorodne. Zob. Wojciech Paszyński, Czarna legenda „Nowych Aten” Benedykta Chmielowskiego i próby jej przezwyciężenia, „Prace Historyczne” 141 (2014), nr 1, s. 37-59. Tu zebrano i omówiono literaturę przedmiotu. 
je - opierając się na naukowych autorytetach - porządkującemu opisowi w dziele o charakterze encyklopedycznym ${ }^{3}$. Stając wobec nadmiaru ksiąg, zasadniczego problemu wczesnonowożytnej nauki ${ }^{4}$, próbował zachować jedność tej wiedzy: mierzył się z rozbieżnymi opiniami autorytetów, kompilował rozmaite treści, a zaufaniem w tej pracy obdarzał uczonych katolickich, zwłaszcza jezuitów z nurtu scientia curiosa.

Chmielowski urodził się na Wołyniu, studiował we lwowskim kolegium jezuitów, został księdzem, od roku 1725 do śmierci był proboszczem w Firlejowie, wsi w dekanacie rohatyńskim (którego był dziekanem) leżącej przy drodze na Przemyślany, między Stanisławowem a Lwowem ${ }^{5}$. W jego czasach i nieopodal w atmosferze mistycyzmu, ruchu mesjanistycznego i nauk kabalistycznych rozwijał się wśród polskich Żydów chasydyzm. Czy Chmielowski, tworzący uniwersalistyczną encyklopedię, dostrzegł te przemiany w świecie pobliskich Żydów ${ }^{6}$ i czy chciał coś na ten temat powiedzieć? Co w ogóle w jego księdze można wyczytać o Żydach oraz ich sprawach?

Informacje w Nowych Atenach podawane są w porządku tematycznych części, odmiennie w różnych miejscach dzieła - zależnie od treści i charakteru konkretnego rozdziału, a także konwencji piśmiennictwa dotyczącego danego tematu, które akurat wykorzystał Chmielowski. Odsyła on przy tym do licznych autorów i ksiąg, co jednak wcale nie oznacza, że rzeczywiście je studiował; często erudycyjne odnośniki przejmował po prostu z bezpośredniego źródła, nie zawsze w takiej roli wyraźnie ujawnionego ${ }^{7}$ (co

${ }^{3}$ Szerzej o tym modelu: Anthony Grafton, The World of the Polyhistors: Humanism and Encyclopedism, „Central European History” 18 (1985), nr 1, s. 31-47; Cesare Vasoli, Encyklopedyzm w XVII wieku, thum. Adam Aduszkiewicz, Warszawa 1996.

${ }^{4} \mathrm{O}$ sposobach radzenia sobie z tym problemem zob. Ann Blair, Reading Strategies for Coping with Information Overload ca. 1550-1700, „Journal of the History of Ideas” 64 (2003), nr 1, s. 11-28; Brian W. Ogilvie, The Many Books of Nature: Renaissance Naturalists and Information Overload, „Journal of the History of Ideas” 64 (2003), nr 1, s. 29-40; Wiesław Pawlak, De eruditione comparanda in humanioribus. Studia z dziejów erudycji humanistycznej w XVII wieku, Lublin 2012.

${ }^{5}$ Zob.: Wincenty Ogrodziński, Chmielowski Joachim Benedykt, [w:] Polski Słownik Biograficzny [dalej: PSB], t. 3, Kraków 1937, s. 341-342.

${ }^{6}$ W samym Firlejowie nie byli oni liczni; według badaczy „W r. 1765 na tym terenie mieszkało tylko kilku Żydów" (Jerzy T. Petrus, Kościót parafialny p.w. św. Stanisława biskupa i męczennika w Firlejowie, [w:] Materiaty do dziejów sztuki sakralnej na ziemiach wschodnich dawnej Rzeczypospolitej. Cz. 1: Kościoły i klasztory rzymskokatolickie dawnego województwa ruskiego, t. 15, red. Jan K. Ostrowski, Kraków 2007, s. 217). Ale w pobliskim Rohatynie istniała w tym czasie gmina żydowska, gdzie działali znani zwolennicy sabataizmu (pochodził stamtąd np. Elisza Szor).

7 Takie metody pracy Chmielowskiego zostały dowiedzione i opisane m.in. w wydaniach krytycznych poszczególnych części Nowych Aten. Zob. stosowne tomy w serii Bibliotheca Curiosa. 
było zresztą szeroko praktykowane przez wczesnonowożytnych erudytów). Ponieważ niektóre informacje mogą tematycznie należeć do różnych rozdziałów Nowych Aten, a dwa ostatnie tomy uzupełniają i rozszerzają wiedzę podaną wcześniej w tomach początkowych, charakterystyczne dla tego dzieła są powtórzenia oraz towarzyszące im niekiedy niekonsekwencje, wynikające z wykorzystania odmiennych źródeł, co w sumie komplikuje orientację w prezentowanych treściach. Powyższe uwagi dotyczą także zagadnień żydowskich.

\section{Żydzi starotestamentowi i późniejsi w ujęciu Chmielowskiego}

Wiele miejsca w Nowych Atenach zajmują izraelskie starożytności, które autor przedstawia przy rozmaitych okazjach, przede wszystkim w części geograficznej pt. „Palestyna albo Ziemia Święta” (II 520-578), uzupełnionej w tomie czwartym informacjami „W Chanaan albo w Judei czyli Palestynie co notandum? Cokolwiek Pismo Święte stawi nam ad sciendum et credendum" (IV 471-516). Biblijny status tych ziem, ich budowli, artefaktów i wydarzeń historycznych każe autorowi potraktować tę materię ze szczególną uwagą, uzasadnioną specjalną pozycją tamtejszych mieszkańców: „Zwali się Żydzi, nim się Chrystus narodził [...], Populus Sanctus” (IV 481), a ich kraina „Zowie się u prawowiernych Terra Promissionis, bo od Boga Izraelitom obiecana; Ziemią Świętą rzeczona [...], że tam prawowierny lud izraelski mieszkał" (II 520).

Informacje z tej partii tekstu oczywiście wykraczają też poza treści biblijne. Część z nich dotyczy spraw przyrodniczych (np. ciekawostek związanych z Morzem Martwym, gdzie „rodzi się bitumen, to jest klej bardzo lipki, krępujący, spajający, który nazywa Dioscorides medyk klejem żydowskim"; II 522), obyczajów i przepisów religijnych (np.: czy wolno było wojować w szabas? jakie ofiary składano Bogu? jaki był strój kapłanów? czym były urim i tummim?; IV 481-485) oraz historii - zwłaszcza dziejów Jerozolimy. Do kwestii jej sławnego zniszczenia przez późniejszego cesarza Tytusa Chmielowski wraca kilkakrotnie (II 526-527; II 547-548; I 366; IV 487-488) i nie szczędzi przy tym zajmujących szczegółów (np. o Żydówce, która podczas głodu oblężenia zjadła własne dziecko ${ }^{8}$;V 492).

${ }^{8} \mathrm{O}$ tym Józef Flawiusz, Wojna żydowska VI, 3, 4. 
Podbój dokonany przez Tytusa jest o tyle istotny, że stanowi cezurę w podejściu autora do Izraelitów. „Odtąd Żydzi po świecie rozproszeni” (IV 488), co opatrzył komentarzem historiozoficznym:

We czterdzieści lat po wyjściu z Egiptu i po błąkaniu na puszczy weszli Żydzi do Ziemi Obiecanej i do Jeruzalem, i znowu w lat 40 po śmierci Chrystusa z niego wygnani. Proszę i to uważać $z$ wielkim nad Boskiemi sądami podziwieniem, [...] iż Chrystus za 30 srebrników tu przedany, tedy podczas tego oblężenia po 30 Żydów za jeden srebrnik przedawano [...]. Iż Chrystus tu pragnął, Żydzi z głodu skórę, gnój z gołębników jedli i dzieci (IV 492-493).

Żydzi starotestamentowi i ich rozmaite sprawy są w Nowych Atenach przedmiotem zwykle życzliwej uwagi ${ }^{9}$. Oto w rozdziale „O ludziach mirabilia" w poszczególnych kategoriach osobliwości na pierwszych miejscach wymieniani są właśnie starożytni herosi żydowscy. I tak „Samson wielkiej siły” otwiera listę osób „ekstraordynaryjnej mocy”, Mojżesz, Jozue, Dawid, Machabeusze to „belliciosi albo kawaleryjskiego serca ludzie”, „Judith, tryumfatorka Holoferna” jest przykładem „dam heroicznych”, Józef, Zuzanna - „czystości cnotą zaleceni”, Saul i Dawid w dziale „podłych elewacyja” ilustrują wyniesienie człowieka z niskiego stanu (I 686 i n.). W części prezentującej chronologię dziejów świata wydarzenia z historii Żydów zajmują ważne miejsce właśnie do czasu wojny z Tytusem (I 204208), na liście wypadków z nowszych czasów pojawiają się zaś sporadycznie i w zgoła innej funkcji:

W toletańskim powiecie w Hiszpanii, rozprzestrzeniając Żyd winnicę swoję, w skale znalazł księgę z kart drzewianych pisaną po łacinie, grecku, hebrajsku, inter cetera było: „Syn się Boży narodzi na świecie z Panny Maryi i ucierpi za zbawienie ludzkie”. Żyd ten nawrócił się z całym domem. Roku Pańskiego 1260 (I 212).

Właśnie Żydów konwertytów Chmielowski przywołuje jako autorów wiarygodnych i dobrze poinformowanych w sprawach religii oraz obyczajów ich pierwotnej kultury. Jest nim np. „Egesipus, z żyda chrześcijanin” (III 627), czyli św. Hegezyp, historyk kościelny z II w.; „Galatinus, z żyda wierny chrześcijanin" (I 2), czyli Pietro Colonna Galatino (ok. 1460-1540), uczony franciszkanin żydowskiego pochodzenia. Jest takim też „Julius

${ }^{9}$ Dotyczy to nawet ich sprzeniewierzania się Bogu, które zyskuje walor pouczenia dla śledzących te dzieje. Oto jedną z przyczyn skażenia państw ma być „niepohamowana carnalitas w prawowiernych”, co Chmielowski ilustruje przykładem: „Że Izraelitowie na puszczy nie pustelnicy, lecz zalotnicy, że bożkowi Beelphegor czynią z nieczystości swojej ofiary, że z córkami Moabitów na sprosną oddali się akcyją, 24 tysiące zginęło swywolników” (I 429). Por. Lb 25. 
Mauroaenus, z rabina chrześcijanin" (I 1067) - choć w tym przypadku Chmielowski przekręcił nazwisko, w istocie był to bowiem XVII-wieczny konwertyta Giulio Morosini (wcześniej: Samuel Nahmias), w zlatynizowanej wersji: Maurocenus, znany Chmielowskiemu tylko z drugiej ręki ${ }^{10}$. Całą listę rabinów konwertytów zamieszcza Chmielowski w katalogu osób pamięci godnych. Znajduje się tu obszerniejsze hasło pt. „Rabini” z wyjaśnieniem:

Rabini są to żydowscy mistrzowie, doktorowie, od słówka rabbi, to jest magister rzeczeni, jedni przed Chrystusa Pana narodzeniem żyjący, drudzy po narodzeniu. I tak rabbi Joram, rabbi Hakkados, rabbi Simeon Ben-Asrain pisali, jakoby ducha prorockiego pełni byli, o Mesyjasza przyszłego narodzeniu [...]. Inni zaś z żydów chrześcijanami pozostawszy, jako to rabbi Joseph Samla z Samaryi, rabbi Juda Ben Sammia z Cezaryi, rabbi Mardochaeus Ben Jona jerozolimczyk, rabbi Ben Jusal z Joppe miasta przeciw Żydom w ślepocie swej zaciętym zaostrzyli pióro (III 681).

Te informacje Chmielowski przepisał bez odesłania do źródła z monumentalnego komentarza biblijnego, zresztą częściej wykorzystywanego w Nowych Atenach, który ułożył belgijski jezuita Jacobus Tirinus (15801636) ${ }^{11}$. Bezpośrednio dalej polski autor uzupełnia tę listę:

Do których liczby należy Samuel, z rabina chrześcijanin, natione Afrykańczyk, ojczyzną z Marochium tamecznego kraju, który po arabsku napisał w roku 1000 książkę czy-li list do rabina Izaaka w tymże kraju będącego, z wielkiemi i jasnemi dowodami o przyściu już spełnionym Mesyjasza Chrystusa Pana; którą książkę Alfons Bonhomo Hiszpan dominikan po łacinie przetłumaczył z arabskiego roku 1339, już nie raz w różnym języku przedrukowaną, którą i ja czytałem całę z profitem znacznym, jako ją często cytuję (III 681).

Ów list rabina Samuela z takimi właśnie informacjami o losach tekstu wydany został w 1733 r. przez Jakuba Pawła Radlińskiego ${ }^{12}$, proboszcza

${ }^{10}$ Ta błędna forma nazwiska widnieje też w pierwszym wydaniu Nowych Aten (I 716). Chmielowski powołuje się przy tej okazji także na drugiego kościelnego pisarza, ważnego informatora w zakresie tematów żydowskich, którym był Joannes Clericatus (Giovanni Chiericato, 1633-1717). To w jego dziele przywołany został poprawnie ów „Julius Maurocenus, olim rabbinus" (Joannes Clericatus, De venerabili Eucharistiae sacramento decisiones..., XVII, 1-2; Venetiis 1705, s. 99) jako autorytet w kwestii paschalnych obyczajów żydowskich. Maurocenus opisał je w dziele wydanym jako: Giulio Morosini, Via della fede mostrata a'gli Ebrei..., II, 30 (Roma 1683, s. 550-568).

11 Jacobus Tirinus, Commentarius in Sacram Scripturam..., Lugduni 1683, t. 2, s. 17 (w osobno paginowanym dziale „Index auctorum”).

${ }_{12}$ Prawda chrześcijańska od nieprzyjaciela swego zeznana..., Lublin 1733 (i wydania następne). Radliński jest tu autorem obszernego suplementu wymierzonego w Żydów (por. pełny tytuł w: Karol Estreicher, Bibliografia polska, t. 27, Kraków 1929, s. 60-61). Sam list wcześniej był już znany w wersji polskiej jako: Epistola albo list rabi Samuela Żyda ku drugie- 
leżajskiego, którego dzieło było istotnym źródłem wiedzy Chmielowskiego (do czego się wyraźnie przyznał) także o innych, dalej omawianych problemach żydowskich.

Chmielowski nie uznawał wszakże przyjmowania chrześcijaństwa przez Żydów za pożyteczne w każdym wypadku, skoro z wyrzutem ujawnia zgoła inne niż religijne przyczyny takiego ich postępowania: „A choć który żydowską z serca zrzuci ślepotę, tedy na to, aby lepiej Chocim, Berlin, Frankfort obaczył. Żadnego statku nabożeństwa w nim nie masz: mutavit religionem, non mores" (IV 386). Trudno jednak orzec, czy jest to wynik osobistych spostrzeżeń autora, czy obiegowy osąd na temat rzeczywiście przecież zachodzących wówczas konwersji ${ }^{13}$.

W innych partiach encyklopedii Chmielowski poświęca uwagę dalszym sprawom wywodzącym się z żydowskiej starożytności. W obszernej części pt. „Judaismus” (I 1061-1094) omawia dzieje narodu wybranego, stronnictwa religijne, święta żydowskie; wyjaśnia, czym jest Święto Trąbek, Święto Namiotów „vulgo Kuczek”, „fest wesołości Phur albo Phurim”, a szczególnie interesuje go Pascha. Przywołuje osobliwości związane ze świętowaniem szabasu („trzewików, że były podkute, obuć nie chcieli”; „listu odpieczętować nie ważyli się w dzień sabaszu”; I 1069), wymienia nazwy żydowskich miesięcy (I 1065-1069). W tej części mieści się też wywód skierowany przeciw poglądom Żydów, którzy przeczą Trójcy Świętej i Chrystusowi-Mesjaszowi, z argumentami teologicznymi i z odniesieniem do Pisma, także do znaczeń słów hebrajskich, zmierzający do konkluzji o odrzuceniu przez Boga Żydów i wybraniu pogan (I 1077-1094). Dziekan rohatyński kończy tę część uwagą: „Na te wszystkie racyje oczywiste są jak marmury Żydzi, ślepi jak [...] krety, głusi jako bałwany” (I 1094).

\section{Talmud w tekstach Nowych Aten}

Wiele miejsca w dziale „Judaismus” Chmielowski poświęcił Talmudowi, uzupełniając jeszcze te wiadomości w tomie trzecim, gdzie przedstawił w zwarty sposób informacje o rabinach odpowiedzialnych za powstanie tych ksiąg, o losach Talmudu Jerozolimskiego i Babilońskiego, o ich podziale oraz dekretach papieży je zwalczających (III 683-684), przy

mu rabi Izaakowi Żydowi postany, że Jezus Nazarański prawdziwem jest Mesyjaszem, Kraków 1538.

${ }^{13}$ O czym zob. Adam Kaźmierczyk, Rodzitem się Żydem... Konwersje Żydów w Rzeczypospolitej XVII-XVIII wieku, Kraków 2015. 
czym nie ujawnił, że przepisał to - choć nie wszędzie dokładnie - z dzieła Tirina ${ }^{14}$. Oto przykładowe różnice: Talmud Jerozolimski składa się z części „Misna”, którą zebrał rabin Judas Hakkadosch (u Tirina: Haccados), a jego część druga nazywa się „Themara” (u Tirina: „Ghemara”).

Także w dziale „Judaismus” zamieścił te informacje o Talmudzie Jerozolimskim, jego dziejach i częściach („Misna” i „Ghema”; I 1071) oraz o Talmudzie Babilońskim, powołał się na kilka autorytetów, przy czym w istocie jego źródłem był chyba wspomniany już Joannes Clericatus ${ }^{15}$. Tuż jednak niżej Chmielowski przedstawił konkurencyjny podział: „Keser Moschem, to jest Granice”, „Keser Naasym, to jest Niewiasty”, „Keser Thensesim to jest Świętości”, „Jezebor, to jest Zbawiciel”, który znalazł w książce Jana Achacego Kmity pt. Talmud..., co na karcie tytułowej zapisano z użyciem hebrajskich czcionek: דומלת [sic!] abo wiara żydowska (Kraków 1610).

Kmita jest autorem całej serii broszur wymierzonych w Żydów, powstałych w wyniku jakiegoś z nimi zatargu, które wyróżniają się wśród antyjudaików z początków XVII w. - ich ostrzem bowiem jest żart i interesująca forma literacka ${ }^{16}$. Jego Talmud... zawiera katalog osobliwych treści rzekomo wydobytych z tej świętej księgi, przypisanych różnym, wymienianym tu rabinom ${ }^{17}$, stanowiąc w istocie zestaw żartobliwy, mający być - jak ujął to Kmita na karcie tytułowej - „pospólstwu krotofilny”. Stąd Chmielowski m.in. zaczerpną ${ }^{18}$ treści zapisane w swej „,Tabeli talmudyckich baśni” (I 1071-1077), wypełnionej osobliwościami: „Pan Bóg igra z rybą

14 Tirinus, Commentarius in Sacram Scripturam..., t. 2, s. 19 (w osobno paginowanym dziale „Index auctorum”).

${ }_{15}$ Por. przyp. 10. O Talmudzie: Joannes Clericatus, De sacrosancto missae sacrificio decisiones..., Venetiis 1727, s. 165 (tu: dec. 24, nr 37-38).

${ }_{16}$ Zob.: Maria Cytowska, Zbigniew Wojas, Kmita Jan Achacy, [w:] PSB, t. 13, Wrocław 1967, s. 93-94. Szerzej o treści tych ksiąg: Kazimierz Bartoszewicz, Antysemityzm w literaturze polskiej XV-XVII w., Warszawa 1914, s. 60-73; Anna Michałowska-Mycielska, Jan Achacy Kmita: An Anti-Jewish Writer of the First Half of the 17th Century, „Scripta Judaica Cracoviensia" 4 (2006), s. 11-15. Zob. też Robert Kaśków, Zainteresowanie Żydami i kultura żydowska w XVI i na poczatcu XVII w. w Polsce, praca doktorska napisana pod kierunkiem prof. dra hab. Jerzego Woronczaka, Uniwersytet Wrocławski 1996; sygn. Dr 248 w Bibliotece Instytutu Filologii Polskiej Uniwersytetu Wrocławskiego.

${ }^{17}$ Kaśków twierdzi, że przytoczony powyżej podział Talmudu na cztery części „dowodzi, że autor [scil. Kmita] nie znał świętej księgi Żydów, podobnie jak nie rozumiał po hebrajsku”. Komentuje też zamieszczony przez Kmitę katalog osobliwych treści: „Są wśród nich zarówno autentyczne sentencje czy legendy talmudyczne, aczkolwiek mocno zniekształcone i wypaczone, jak również niedorzeczne stwierdzenia [...]. Prawda nierozerwalnie splata się tu ze zmyśleniem”. Tamże, s. 267-268.

${ }^{18}$ W opisie wyprawy Żydów do Raju w sprawie mesjasza (I 1075-1076) Chmielowski wykorzystał też inną, ewidentnie żartobliwą broszurę Kmity pt. Ein send Breief abo list od 
Leviathan, otaczającą świat cały i trzymającą się za ogon”, „rabin Saul twierdzi, że Bóg od zburzenia Jerozolimy nie śmieje się, owszem płacze trzy razy na dzień, widząc mizeryję Żydów”; „rabbi Ozyjasz baje, że Ewa z zwodzicielem wężem jak z mężem concubuit”; „bają, że Pan Bóg wtenczas na głowę boleje, gdy Żyd choruje" (I 1072) itd. Przy czym niektóre z tych sentencji Chmielowski opatrzył własnym komentarzem, wchodząc z nimi w poważną dyskusję, np. odnośnie do ostatniej z przytoczonych kwestii zapisał: „Czyżby nie wolał Pan Żyda uzdrowić, niżeli z nim chorować, albo cale nie dopuszczać na niego choroby, żeby i sam nie chorował?”. W sprawie nadziei mesjańskich: „Rabbi Chenina uczy, iż wtenczas na świat przyjdzie mesyjasz, kiedy [...] król nastanie opressor Żydów”, co komentuje: „Czyż nie był taki Filip III, król hiszpański, który Żydów z państw swoi<ch $>9$ kroć sto tysięcy wypędził - a czemuż mesyjasz dla nich nie przyszedł?” (I 1073) itd.

Takie uwagi Chmielowskiego zdają się świadczyć, że potraktował dziełka Kmity jako teksty napisane serio. Początek swej „Tabeli talmudyckich baśni” opatrzył wprawdzie uwagą, że służyć ma do wyśmiania („ad ridendum”), ale też do wykazania autentycznych błędów żydowskich - zostały tu one „Przez różnych autorów hebrajski dobrze umiejących język w Talmudach upatrzone, przeze mnie tu zebrane ad ridendum et videndum, jak błądzą Żydzi” (I 1071). Na końcu zaś „Tabeli” odnotował oświadczenie Żydów: „tego nie masz w Talmudach”, by odpowiedzieć: „Więcej ja wierzę mądrym i dobrym katolikom, Hebraicam linguam arte umiejącym i czytającym z ciekawością księgi ich, niżeli kłamliwym Żydom” (I 1077) ${ }^{19}$.

W istocie autor Nowych Aten miał też inne powody, by przyjąć rewelacje z Kmity za dobrą monetę. W czasach Chmielowskiego takie dziwaczne treści właśnie jako prawdziwe przedstawił wspomniany już Radliński w znanej Chmielowskiemu książce Prawda chrześcijańska od nieprzyjaciela swego zeznana (Lublin 1733), gdzie rozdział „Które są i jakie talmudowe baśnie albo raczej bluźnierstwa?"20 kończy się zapewnieniem, że obeznani w hebrajszczyźnie uczeni chrześcijańscy znaleźli w Talmudzie owe „błędy i bluźnierstwa”. A przytoczone tu zostały one z innych źródeł, nie z Kmity.

Żydów polskich po mesyjasza, który, jako Żydzi wierza, w Raju siedzi czekając czasu przyścia swego..., [b.m., po 1614].

${ }^{19}$ Zapisał też przy tym inną ewentualność: Talmudy skazywane na spalenie za bluźnierstwa i błędy mogły zostać w katolickich krajach już oczyszczone, ale egzemplarze używane w Turcji, w Arabii, a nawet w krajach protestanckich mogą zawierać te pierwotne treści.

${ }^{20}$ Prawda chrześcijańska..., s. 449-463. 
Także sam Chmielowski, omawiając treści Talmudu, przywołuje poza Kmitą inne autorytety (I 1074), wśród których szczególnie ważni dla tej materii są dwaj autorzy: wspominany już Clericatus ${ }^{21}$ oraz „Masquardus autor", znany Chmielowskiemu chyba tylko poprzez tego pierwszego ${ }^{22}$.

Ów „Masquardus”, tak nazywany także na innych stronach Nowych Aten $^{23}$, to Marquardus de Susannis, autor wydanego w XVI w. kompilacyjnego dzieła pt. Tractatus de Judaeis, rzeczywiście zawierającego passus stosownej treści ${ }^{24}$. Z tych czasów pochodzą wszakże książki o wiele ważniejsze dla omawianego tematu, dowodzące, że tworzenie szczegółowych zestawień osobliwości talmudycznych ma odległe i erudycyjne tradycje. Sławny biblista, dominikanin żydowskiego pochodzenia, Sykstus ze Sieny (1520-1569) w dziele Bibliotheca sancta zamieścił część pt. „Index errorum aliquot, quos ex innumeris stultitiis, blasphemiis et impietatibus Thalmudici operis collegimus”, dodając do owych „błędów” odsyłacze z lokalizacjami w Talmudzie ${ }^{25}$. I ta właśnie część była u nas rozpropagowana - została wydana drukiem w wersji dwujęzycznej, łacińsko-polskiej, przygotowanej przez Jakuba Górskiego, teologa i uczonego, rektora Akademii Krakowskiej $^{26}$.

To znamienne, że w czasach Chmielowskiego także inni autorzy kościelni w Polsce - Jan Stanisław Wujkowski i Franciszek Antoni Kobielski - gdy podejmowali tematy żydowskie, wprowadzili do swych tekstów podobne zestawienia osobliwości z Talmudu. Były one konwencjonalnym wypełnieniem tego rodzaju piśmiennictwa ${ }^{27}$.

${ }^{21}$ Zob. obszerny katalog tych „błędów”: Clericatus, De sacrosancto missae sacrificio decisiones..., s. 166-167 (tu: dec. 24, nr 39-40).

${ }^{22}$ Choć może nawet obaj zostali przywołani w Nowych Atenach jedynie za pośrednictwem Radlińskiego, skoro to on przy swym katalogu „talmudowych baśni” odsyła właśnie: „Joannes Clericatus ex Masquardo”. Prawda chrześcijańska..., s. 462.

${ }^{23}$ Por. I 220: „Talmudy uczą żydowskie, że Bóg na cherubinach lata, aby co dzień zlustrował 18 tysięcy światów, jako to pisze Masquardus autor”.

${ }^{24}$ Marquardus de Susannis, Tractatus de Judaeis et aliis infidelibus, Venetiis 1558, k. 114 (III, 1, nr 49).

${ }^{25}$ Sixtus Senensis, Bibliotheca sancta..., Venetiis 1566, s. 199-202.

${ }^{26}$ Na karcie tytułowej widnieje tytuł łaciński i polski; w wersji polskiej to: Jakub Górski, Okazanie kilka błędów z nierozlicznego bluźnierstwa, szaleństwa i niepobożności z Talmuta żydowskiego zebranych, z których może każdy zrozumieć, jako bładza i jako wielkimi sa nieprzyjaciótmi krześcijanom [...]. Wyjęte z wtórych ksiąg „Biblijoteki świętej” Syksta Seńskiego, Kraków 1569.

${ }_{27}$ Zob. stosowne partie ksiąg: Jan Stanisław Wujkowski, Kontrowersyje polskie abo prawda otwierająca dysydenckie oczy [...]. Z przydatkiem o niewierności i ślepocie żydowskiej..., Warszawa 1737, s. 319-320; Franciszek Antoni Kobielski, Światło na oświecenie narodu niewiernego, to jest kazania w synagogach żydowskich miane..., Lwów 1746, s. 187-188. 
Wśród autorów, których Chmielowski przywołał w związku z kontrowersyjnymi opiniami rabinów, jest również najważniejszy uczony nurtu scientia curiosa, „ostatni człowiek, który wiedział wszystko” - jezuita Athanasius Kircher $^{28}$. Zaczerpnięte z jego tekstów informacje o biblijnym gigancie Ogu, królu Bazanu, dziekan rohatyński przedstawił jako nauki mędrców żydowskich i w związku z tym skrytykował Izraelitów w ogóle: „W Kircherze zaś czytam, że ten Og, według rabinów, Noego szukając po wodach potopowych, 15 łokci nad góry wyższych, tej wody miał tylko po kolana. Większe głupstwo Żydów nad tego olbrzyma!” (I 1073). Krytyka wyrażona przez Chmielowskiego jest tu jednak pomylona, w istocie bowiem Kircher tę uwagę, że Og miał wody po kolana, przytoczył nie za rabinami, ale z tradycji arabskiej ${ }^{29}$.

Chmielowski poświęcił zatem wiele miejsca tematom żydowskim, a kierowała nim przede wszystkim chęć objaśnienia rozmaitych realiów biblijnych. Objaśniwszy je, postawił kwestię: „Czy obligowani chrześcijanie obserwować [tj. przestrzegać, zachowywać - J.K.] ceremonije starozakonne żydowskie?”. I odpowiedział jednoznacznie: „Nie jesteśmy [...] obligowani Starego Testamentu obserwować ceremonije, na przykład obrzezanie, Wielkanoc żydowskim trybem, obserwancyje w potrawach, w stroju" (I 1008). A omawiając zawiłości w przekładach hebrajskich ksiąg starotestamentowych, zapisał przestrogę: „Nie należy teraz do Żydów z teraźniejszemi chodzić heretykami po eksplikacyje Pisma” (III 596).

Ta biblijna perspektywa każe mu też poczynić uwagi o języku hebrajskim, który „bierze prym jako najpierwszy na świecie”. Zanotował: „Tego języka usum mają wszyscy Żydzi, gdziekolwiek in orbe terrarum się znajdujący, do nabożeństwa i pisma go zażywając; do dyskursu zaś familijarnego adhibent język ten, który jest ojczysty w tym kraju, gdzie się znajdują”. I dodał: „Nasi polscy Żydzi mówią językiem niemieckim, polskim, ruskim” (II 747-748).

\section{„Czy wszędzie po świecie są Żydzi?”}

W Nowych Atenach jest także mowa o Żydach z czasów bliższych autorowi - zarówno zamieszkujących Rzeczpospolitą, jak i inne kraje.

${ }^{28}$ Athanasius Kircher: The Last Man Who Knew Everything, red. Paula Findlen, London 2004. Zob. też: Joscelyn Godwin, Athanasius Kircher: A Renaissance Man and the Quest for Lost Knowledge, London 1979.

${ }^{29}$ Athanasius Kircher, Mundus subterraneus..., Amstelodami 1665, t. 2, s. 60; tenże, Arca Noё..., Amstelodami 1675, s. 9. 
W końcowej części „Judaismus” znalazł się passus pt. „Czy wszędzie po świecie są Żydzi?”:

Odpowiadam, że wszędzie ich pełno: w Azyi, w Afryce, [...] dopieroż w Europie po państwach różnych [...]. Ma ich niemało Polska i Litwa, jakoż powiedziano o Polskiej Koronie, że jest infernus rusticorum, paradisus Judaeorum. Nadali im praw, przywilejów, wolności Polacy, książęta i królowie (I 1094).

Przy tym autor wyjaśnia, że Kazimierz Wielki ulegał perswazjom „Estery Żydówki faworytki” ${ }^{\prime 30}$. Pisze też o historycznych wypędzeniach Żydów z rozmaitych krain, zwłaszcza z Hiszpanii (do tej sprawy powraca zresztą kilkukrotnie w różnych miejscach ${ }^{31}$ ), zauważając: ,Jedyna Hiszpanija ich czosnkiem nie śmierdzi” (I 1094). Ten kraj i jego mieszkańcy cieszą się szczególnym uznaniem Chmielowskiego, skoro „Hiszpani są catholicissimi: ni Żyda, ni heretyków nie cierpią, za co sint in benedictione" (II 37). Wzmiankuje też o wypędzeniach w Polsce, mających mniejszą skalę, gdy rugowano Żydów z Warmii, z Sącza, z Warszawy, z Biecza, „świeżo zaś z Śląska A.D. 1739 edyktem na ustąpienie dekretowani”, co podsumował: „przecież oni do tych miejsc zaglądają” (I 1094).

Uwagi o zagranicznych i polskich Żydach Chmielowski umieszczał też w działach geograficznych i w zestawieniach ciekawostek właściwych danemu miejscu - zasadniczo jednak są to notki lakoniczne. Opisując galerię osobliwości elektorów saskich, odnotowuje: „Jest tam Biblia hebrajska pisana, za którą 20 tysięcy talerów dawali Żydzi” (II 240); przy Awinionie ,jest miasteczko żydowskie [...], gdzie ich jest na 500 chodzących w żółtych kapeluszach, a Żydówki w żółtych koronkach u czapek" (IV 193); w Amsterdamie jest ,żydowska synagoga albo bożnica wielka dla Żydów portugalskich” (II 248).

A w sprawach rodzimych: w dziale pt. „Co który jeszcze kraj Polski ma osobliwego?" wspomina Batoh na Podolu jako miejsce fatalne, przedstawia okolice Trembowli na Podolu jako obfitujące w kamień, a pomiędzy te informacje wstawia zdanie: „Grodno Żydów pełne i Brzeście Litewskie, Warmia ich nie ma" (II 334). Wyliczając zarazy trapiące kraj, precyzuje: „Roku 1710 w Wilnie chrześcijan wymarło 20 tysięcy, Żydów 4 tysiące” (I 219). Aż połowę hasła poświęconego Poznaniowi w opisie geograficznym Polski wypełnia opowieścią o hostiach rzekomo sprofanowanych przez

\footnotetext{
${ }^{30}$ Por. też o tym w części poświęconej władcom Polski, gdzie czytamy, że Kazimierza „Żydówka Esterka emollivit i dla Żydów wiele wyrobiła przywilejów” (II 347).

${ }^{31}$ Por. także II 18; II 31; IV 181; IV 386.
} 
Żydów w końcu XIV w. (II 317). Krótko rejestruje, że na Podgórzu zbójcy napadają także na Żydów (IV 341), że w pokuckiej krainie wśród kupców Stanisławowa są Żydzi (IV 342), że we Lwowie stoi „bożnic żydowskich murowanych 2” (II 315), że w Krakowie „Żydzi z miasta wypędzeni na Kazimierz, gdyż dla ich tam mieszkania ogień częsty panował” i teraz „na tym Kazimierzu Żydzi mają swoje miasto" (IV 329).

Niekiedy uwagi jego są tak błahe, że ich pożytek dla dzieła encyklopedycznego bywa wątpliwy; czasem jednak mają cel żartobliwy, co jest charakterystyczne dla stylu wywodów Chmielowskiego, opartych na grach słownych i konstrukcjach konceptystycznych. Taka uwaga o trzech „szabasach” znalazła się w opisie Wilna: „Tria sabbata tamtejsi obserwują obywatele: Tatarzy tam, od Witolda książęcia osadzeni, mający swoje przedmieście, będąc mahometańskiej religii obserwują piątek, Żydzi secundum Legem Moysis - sobotę, chrześcijanie - niedzielę" (II 320-321).

Spotykamy jednak także noty, które - choć krótkie - są bardziej doniosłe, ponieważ zawierają wiadomości nietypowe. Wiąże się to na przykład z życzliwym komentarzem Chmielowskiego, gdy pisze o Brześciu Litewskim: „W tym tu mieście jest sławna żydowska synagoga, z której rabinów innym subministrant miastom dobrze uczonych" (IV 361). Wśród świąt żydowskich w rozdziale „Judaismus” zamieścił informację o jednym specyficznie rodzimym: „Polscy Żydzi celebrują dzień 17 czerwca alias post obchodzą ścisły, nawet dzieciom piersi nie dają, a to na pamiątkę kilka tysięcy Żydów pobitych na Ukrainie przez Chmielnickiego, hetmana kozackiego" (I 1068-1069).

\section{„Pańscy Żydzi”}

W części poświęconej zarządzaniu majątkami ziemskimi, adresowanej do panów feudalnych, znalazły się konstatacje o arendarzach, jednoznacznie utożsamianych z Żydami:

Arendarza, mianowicie Żyda, jeśli pan ma w dobrach swoich, powinien go ex millibus wybrać, aby był bez noty, z kredytem wielkim, już bywałego na arendzie, nie zdziercę, któryby z pana się i jego poddanych zapomagał dopiero, żeby wielkiej z sobą nie miał familii [...]. Zboża, drew, poddanych nie dawać mu do arendy, bo jakaś subiekcyja i niewolnictwo, aby nad żydowskiemi pan myślał wygodami. Lepiej trochę mniejszą kontentować się arendą, a mieć pokój (III 362-363).

Cały dotyczący tej materii podrozdział ma rzeczowy charakter, przedstawia kalkulacje co do zysków i strat powstających w relacji między panem 
a jego zarządcą. Żydowska tożsamość tego ostatniego każe Chmielowskiemu zastrzec, by w porządku praktyk ekonomicznych i ładu codziennego życia zachowane były także potrzeby chrześcijan, bytujących wobec takiego dzierżawcy. „Arendarz Żyd nie powinien parobka i dzi<e > wki chrześcijan trzymać, bo to niechrzest, bo to niewierny" (III 363), a bliższe z nim obcowanie źle wpływa na czeladź chrześcijańską, deprawując ją religijnie; niech sam nie pracuje ciężko w święta chrześcijańskie; niech nie zarządza wycinką drzew, „bo Żydzi się na tym nie znają” (III 364-365). Autor radzi feudalnemu panu, by z szlachecką wyższością odnosił się do żydowskiego dzierżawcy, ale by zachował przy tym stosowny umiar, postępując po ludzku, a w razie niebezpieczeństwa nie odmawiał mu swej możnej opieki:

Dziwno mi, że panowie boją się Żyda urazić - kontraktując z nim, zaraz przestrzec, czego się ma spodziewać. Że poddanych drze, z nich się panoszy, jeszcze mu pochlebować? Lepiej mu serio się stawić po pańsku, a on niech będzie subiectus po arendarsku jako winowajca skarbowy. Co krzywdy żadnej czynić mu nie należy jako bliźniemu ani w opresyi denegare protectionem (III 365).

\section{„Błędy Żydów grube”}

Inaczej jednak o relacjach między panami a Żydami mówi się w innych partiach Nowych Aten - co jest kolejnym dowodem, że przekazywane przez Chmielowskiego treści zależą od konwencji przynależnych poszczególnym rozdziałom, zwłaszcza zaś tradycji wykorzystywanego piśmiennictwa. Oto bowiem w tomie czwartym znajduje się rozdział pt. „Dwie rzeczy Polakom i Litwie pożądane: Żydów i heretyków vulgo dysydentów oddalenie albo pod rygorem praw tolerowanie, bo te są dwie mocne miny polskiej ruiny". Część początkowa tego rozdziału dotyczy Żydów (IV 383-390) i tak zachęca odbiorcę do wzmożenia uwagi: „Piękna to i potrzebna do czytania materyja”. Tu o tzw. pańskich Żydach ${ }^{32} \mathrm{i}$ arendarzach autor wypowiada się zupełnie inaczej niż w części ekonomicznej: „Ciężkie też scandalum i nie godzi się panom, aby Żydów w dobrach swoich nad chrześcijanami czynili administratorami, pisarzami, komisarzami ani im dóbr, folwarków należy puszczać w arendę" (IV 387). A objaśniając, dlaczego jednak takie scandalum ma miejsce, zapisał: „przez czary i oferty częste panów opanowali

${ }^{32}$ O których zob. szerzej: Moshe Rosman, Żydzi pańscy. Stosunki magnacko-żydowskie w Rzeczypospolitej XVIII wieku, thum. Wojciech Tyszka, Warszawa 2005. 
serca" (IV 389). Był to zarzut mocno ugruntowany w piśmiennictwie antyżydowskim ${ }^{33}$.

Jeszcze bardziej zakorzenione było, jak wiadomo, oskarżenie o popełnianie mordów rytualnych, pobieranie chrześcijańskiej krwi i stosowanie jej do różnych praktyk, zwłaszcza magicznych ${ }^{34}$. Problematyka ta jest obecna także w Nowych Atenach - nie tylko we wskazanej partii tomu czwartego, ale i wcześniej, w części „Judaismus”; tam, przy próbie całościowego ogarnięcia spraw żydowskich, Chmielowski uznał, że należy odnieść się także do tych problemów - jako konwencjonalnych i spodziewanych przez odbiorców. Zestawił więc rozmaite „błędy Żydów grube”, wśród których na końcu znalazł się krótki (zaledwie piętnastowersowy) podrozdział, zaczynający się od słów: „Krwie chrześcijańskiej są bardzo apetyczni” (I 1070). Zawiera on garść utartych, obiegowych motywów należących do tego tematu. Wymienia najpierw Szymona z Trydentu, słynną dziecięcą ofiarę, z adnotacją: „teste Nadasi 24 Martii”. Ów „Nadasi” to János Nádasi (1613-1679), węgierski jezuita, autor licznych dzieł, wśród których jest dewocyjna księga Annus caelestis, rodzaj modlitewnika przełożonego na język polski jako Rok niebieski albo przewodnik do szczęśliwej wieczności..., gdzie pod datą 24 marca znajduje się wezwanie modlitewne:

Ś. Szymonie, dziecino w Trydencie, mając miesięcy 29 od Żydów nożyczkami porzezany, igłami po wszytkim ciele pokłuty, rozpięty, różnemi sposobami zakatowany i ukrzyżowany, umierającemu Jezusowi skłonieniem głowy stałeś się męczeńską ofiarą. Święte pacholę, przybądź mi w godzinę śmierci a spraw to, ażebym jeżeli nie za Chrystusa, tedy przynamniej świątobliwie w Chrystusie umierał ${ }^{35}$.

Chmielowski miał w kwestii rytualnych mordów do dyspozycji bardzo rozbudowane piśmiennictwo antyjudaistyczne, obszernie i szczegółowo katalogujące liczne domniemane ofiary oraz ich rzekomych katów ${ }^{36}$, powołał się zaś na dzieło o zupełnie innym charakterze, gdzie sprawa trydenckiego Szymona wyczerpuje się w powyższym cytacie. Drugim,

${ }^{33}$ Szerzej o czarowaniu panów przez Żydów pisałem w artykule pt. Władanie przyjaźnią. Staropolskie uwagi o magicznym jednaniu uczucia, [w:] Przyjaźń w kulturze staropolskiej, red. Agnieszka Czechowicz, Małgorzata Trębska, Lublin 2013, s. 221-229.

${ }^{34}$ Zob. zwłaszcza Ronnie Po-chia Hsia, The Myth of Ritual Murder: Jews and Magic in Reformation Germany, New Haven-London 1988. Literatura przedmiotu do tego tematu jest obszerna.

35 Jan Nadasi, Rok niebieski albo przewodnik do szczęśliwej wieczności..., tłum. Franciszek Iworski, Kalisz 1697, s. 469-470.

${ }^{36}$ Zestawia to piśmiennictwo i obficie cytuje w pierwszej części swej pracy Joanna Tokarska-Bakir, Legendy o krwi. Antropologia przesadu (z cyklu: Obraz osobliwy), Warszawa 2008. 
dwukrotnie przywoływanym tu przez Chmielowskiego autorytetem jest Piotr Hiacynt Pruszcz (1605-ok. 1668), który w dewocyjnym dziele Forteca duchowna Królestwa Polskiego zamieścił niewielki, trzystronicowy rozdział pt. „O okrutnym dziateczek niewinnych [...] morderstwie”. Autor Nowych Aten przeczytał go nieuważnie, skoro napisał: „W Pruszczu autorze naliczyłem dzieci pięcioro chrześcijańskich w samej Polszcze przez żydowską złość pobitych" (I 1070), podczas gdy bez trudu można doliczyć się ich tam dwa razy więcej. Objaśnienie, że termin „Evicomen” oznacza używaną do magicznych celów krew, także oparte zostało na tym dziele, a właściwie na przywołanym w nim jakimś bezimiennym rabinie konwertycie: „wyznaje rabin ochrzczony u Pruszcza autora” (I 1070) ${ }^{37}$. Jedynie książkę wspomnianego już Radlińskiego, do której Chmielowski raz się w tym miejscu odwołał jako do kompendium prawniczego, zaliczyć można do piśmiennictwa bezpośrednio dotyczącego spraw żydowskich, w dodatku mającego charakter encyklopedyczny.

W przydanym później w tomie czwartym rozdziale „Dwie rzeczy Polakom i Litwie pożądane: Żydów i heretyków vulgo dysydentów oddalenie albo pod rygorem praw tolerowanie..." materia wyłożona została obszerniej, bo na ośmiu stronach. Tu w kwestii mordów autor znów zaczyna od Szymona z Trydentu, wzmiankuje też innych zamordowanych, przy czym nie epatuje szczegółami, datami, nazwiskami oskarżonych. O zabitym Dominiku ,świadczy autor Nadasi 31 Augusti in Anno caelesti”38 (IV 383), o innych - Hendrik Engelgrave (1610-1670), belgijski jezuita, autor przywołanego tu pobożnego dzieła o świętych ${ }^{39}$ : „Engelgrave autor w Panteonie wylicza dzieci od Żydów pobitych: Gwilelmów, Hugonów, Richardów, Krzysztofów etc." (IV 383). Takie zbiorowe potraktowanie ofiar sprawia wrażenie jakiegoś pośpiechu w prześlizgiwaniu się nad tą sprawą. Z polskich ofiar wymienia Macieja z Kodnia, odnotowując, że został „ku weneracji podniesiony roku 1713”; napomknął, że byli też inni, poprzestając na odesłaniu: „wylicza [ich] ks. Pruszcz w Fortecy i ks. Radliński” (IV 383). Tuż dalej wśród cytowanych znalazł się jeszcze Piotr

${ }^{37}$ Por. Piotr Hiacynt Pruszcz, Forteca duchowna Królestwa Polskiego..., Kraków 1662, s. 185: „Ex relatione cuiusdam rabini noviter baptizati”.

${ }^{38} \mathrm{~W}$ istocie całe to wskazane świadectwo zamyka się w modlitwie: „Ś. Dominiku, niemowlę m[ęczenniku], od Żydów w Hiszpanii na krzyż przybity, nad którego ciałem światło niebieskie widziane jest, uproś mi światło łaski i chwały, abym Boga widział i kochał na wieki”. Nadasi, Rok niebieski..., s. 1329-1330.

${ }^{39}$ Hendrik Engelgrave, Caeleste pantheon sive caelum novum..., pars posterior, Coloniae Agripinae 1658, s. 141. 
Skarga: „Krew tę dzieci chrześcijańskich według Skargi zwą jubel, to jest jubileus" $"$ (IV 384).

Nieco więcej miejsca poświęcił zupełnie świeżej sprawie: mordu pod Żytomierzem w województwie kijowskim. Jego relacja nie ogranicza się tylko do opisu zbrodni i kary, wykonanej w maju 1753 r., lecz odnosi się do aktywności biskupów (lwowskiego i kijowskiego), którzy „wyszychtowanym tego niewiniątka obrazem i Dekretu drukowaniem"41 (IV 384) dopełnili los zabitego, zapewniając zachowanie o nim pamięci.

To znamienne, że Chmielowski także w tych dodatkach, w specjalnie wydzielonej części antyżydowskiej, konsekwentnie unika odwołań do skrajnych książek z tego nurtu, jak Przecława Mojeckiego Żydowskie okrucieństwa, mordy i zabobony (Kraków 1598) czy komplementarnych pism Sebastiana Miczyńskiego i Sebastiana Śleszkowskiego ${ }^{42}$. Oparcie się na autorach kościelnych, często na książkach dewocyjnych - przecież niespecjalistycznych w kwestiach żydowskich, gdzie ta materia pojawia się niekiedy zupełnie marginalnie - jest być może pewną deklaracją Chmielowskiego. Niewątpliwie zależało mu na wiarygodności przywoływanych autorów, ale też jego zarzuty (konwencjonalne, należące do porządku piśmiennictwa o Żydach) przefiltrowane przez takie książki są chyba łagodniejsze. A przy tym nikt z ówczesnych nie mógł mieć pretensji, że pominął te sprawy milczeniem.

Także dobór dalszego materiału w tym rozdziale nie jest jednoznaczny. Oto bowiem - pisze Chmielowski - w sprawie zarzutu o toczenie krwi „bronią się mocno Żydzi i negują wielkimi przysięgami”, a także wytaczają argumenty. Autor skwitował je wprawdzie stwierdzeniem: „Tak się Żydzi chcą wykręcić", ale przecież wszystkie przytoczył, dając tym samym miejsce obronie żydowskiej. Niektóre z tych argumentów są bezsprzecznie sensowne, jak ten, że gdyby rzeczywiście była im krew potrzebna, kupowaliby

40 Ale przytacza go niedokładnie, bo Skarga używa terminu ,joel, to jest jubileus”. Piotr Skarga, Żywoty świętych..., Kraków 1598, s. 263 (30 marca: „Męczeństwo pacholęcia Szymona trydentskiego").

${ }^{41}$ Chodzi niewątpliwie o druk pt. Dekret o zamęczeniu przez Żydów dziecięcia katolickiego w grodzie żytomierskim..., Kraków 1753. O tym procesie zob. szerzej: Zenon Guldon, Jacek Wijaczka, Procesy o mordy rytualne w Polsce w XVI-XVIII wieku, Kielce 1995, s. 63-64, 141-145.

${ }^{42}$ Sebastian Miczyński, Zwierciadło Korony Polskiej urazy ciężkie i utrapienia wielkie, które ponosi od Żydów, wyrażające..., Kraków [1618]; Sebastian Śleszkowski, Odkrycie zdrad, złośliwych ceremonij, tajemnych rad, praktyk szkodliwych Rzeczypospolitej i straszliwych zamysłów żydowskich..., Brunsbergae 1621. 
chrześcijańskich niewolników w Turcji i tam bez ryzyka ją pozyskiwali (IV 384-385).

W tytule omawianego rozdziału Chmielowski postawił tezę: przydatne byłoby „Żydów [...] oddalenie”. Jednak w poświęconej temu partii tekstu sam dezawuuje ten pomysł na różne sposoby: „Nabrali klasztornych, kościelnych, szlacheckich sum po całej Koronie i Litwie, co może wynieść na kilkanaście milijonów, a przez to, choć sami wygnańcy, do wygnania stali się trudni” (IV 389); prawa o ich wypędzeniu i tak nie udałoby się uchwalić, bo skorumpowani posłowie rwaliby sejmy. Co więcej - w finale ideę ich rugowania prezentuje jako z gruntu złą: udadzą się bowiem do Turcji, gdzie na szkodę chrześcijanom „wiele artes Turka nauczą” (IV 390).

Chmielowski przedstawił długą listę rozmaitych „zbrodni” żydowskich w obyczajach i przekonaniach („Clericatus [...] świadczy”), wśród których wylicza: „Żydzi trzykroć na dzień chrześcijan przeklinają”, „,czarnoksięstwa uczą”, „monetę, trunki fałszują”, „szpiegami bywają dla cudzoziemców”, „Ewnjeliją świętą Talmud żydowski palić każe” itd. (IV 385). Irytują go pewne religijne obrządki:

Na swego Hamana chrześcijan ubogich, opojów stroją scenice, aby osobę Hamana reprezentowali a guzy odnosili od Żydostwa w bużnicach. [...] naszemi potrawami (quanta ignominia), naczyniem brzydzą się, zowiąc to immundum alias treyfe; a chrześcijanie nie skrupulizują (choćby powinni) jeść ich amanowe ucha, kugle (IV 386).

Tę partię tekstu podsumowuje słowami: „A jakże prawdziwy chrześcijanin ten naród tak zły cierpieć może?" (IV 386). Jednak tuż dalej, jakby o tym już nie pamiętał, wymienia cztery pożytki związane z wzajemnym bytowaniem chrześcijan i Żydów, rozważane w aspekcie teologicznym (IV 388-389).

Ład w obustronne relacje chrześcijan i Żydów wprowadzać mają prawa, stąd też autor przedstawia „kanony święte przeciw Żydom” oraz „Statuta i konstytucyje Królestwa Polskiego przeciw Żydom esencyjalne” (IV 387-388), regulujące rozmaite aspekty codziennego życia, pracy, obyczajów. Dotyczą one strojów („Mają Żydzi nosić strój dystyngwowany od chrześcijan, jako w Polszcze czarny z dawna, albo wstęgę na kapeluszu żółtą noszą, jako w cudzych krajach. W Awenijonie kapelusze żółte mają"; IV 387) czy zakazu zatrudniania przez Żydów chrześcijan, a to z różnych powodów, także seksualnych: „,dla uniknienia grzechu, gdyż Stary Zakon nieraz się miesza z Nowym Zakonem w nocy” (IV 387) itd. 
Wymieniwszy te i inne rozmaite zarzuty i problemy, konkluduje: „przecież takich niegodników, szkodników, bluźnierców Chrystusowych a naszych zdzierców tolerują Polacy" (IV 388). Na końcu zaś przywołał „kanony święte”, za których złamanie grozi chrześcijanom klątwa, gwarantujące „starozakonnym” spokój: „nie każą Żydów do wiary chrześcijańskiej przymuszać, na osobach i dobrach ich gwałtu im czynić, świąt ich nie profanować, ani okopisk, ani trupów stamtąd wykopywać” (IV 390).

\section{Czary, magia i kabała}

Wśród „zbrodni” wymienianych w tej partii tekstu znalazło się oskarżenie o czary, tu jednak dość poślednie. Ten okrzepły kulturowo zarzut pod adresem Żydów powraca szerzej, barwniej i różnorodnie w tomie trzecim, w części poświęconej specjalnie wszelkiej magii i czarnoksięstwu. Charakterystyczne jest przy tym włączanie Żydów w chrześcijańską, rozwijającą się stopniowo koncepcję czarnoksięstwa. Typowym bohaterem dla tego nurtu jest obeznany w cyrografach Żyd czarnoksiężnik, pośrednik w relacjach z czartem podjętych przez św. Teofila z Adanu, o którym pisze Chmielowski z erudycyjnym odwołaniem do Symeona Metafrastesa, bizantyjskiego hagiografa (III 212-213), choć legenda o św. Teofilu i Żydzie czarnoksiężniku była powszechnie znana z popularnych żywotów świętych ${ }^{43}$, skąd zapewne już uprzednio dowiedzieli się o niej jego czytelnicy.

Mniej oczywisty w zakresie źródeł magicznych potencji jest zapis o Żydzie Zedechiaszu, choć sam Chmielowski sklasyfikował to jasno:

$\mathrm{Z}$ świeckich też autentycznych historyj moc czarnoksięstwa wielka się pokazuje. Zedechijasz Żyd czarnoksiężnik za Ludwika Pobożnego cesarza człekiem jak piłką do góry rzucał, na ćwierci go poszarpawszy znowu do kupy spajał, wóz z końmi i sianem połykał - według Majolusa in Diebus canicularibus ${ }^{44}$ (III 231).

Nie miał też żadnych wątpliwości, oceniając przyczyny nadzwyczajnych dokonań króla Salomona: „doskonały był naturalista Salomon” (III 220). Znaczy to, że zdobył biegłość w zakresie magii naturalnej, rozpoznał porządek natury, o czym zresztą mówią passusy biblijne (por. $3 \mathrm{Krl}$ 4, 33; Mdr 7, 17-21), na których oparł się Chmielowski:

${ }^{43}$ Skarga, Żywoty świętych..., s. 160-163 (23 lutego).

${ }^{44}$ W sprawie tego połykania wozu: przywołany Simone Maioli użył słowa „absorbebat”, które wprawdzie znaczy połykanie, ale też odnosi się do unoszenia, porwania w górę (co tu jest bardziej prawdopodobne). Simone Maioli, Colloquiorum seu Dierum canicularium continuatio..., Coloniae 1608, s. 258. 
[Salomon miał wiedzę] o drzewach, bydlętach, ptakach, o wężach, rybach, o dyspozycyi świata, o mocy, o dzielności żywiołów, o czasie, o gwiazdach, o cnotach skrytych ziół, jako Księga Mądrości to mu wszytko przypisuje, cap. 7; ale te księgi jego potym spalone są, aby lud o Bogu nie zapomniał był, mogąc mieć pomoc od rzeczy naturalnych (III 220).

Przekonania o znajomości nauki tajemnej przez tego izraelskiego władcę były zresztą $\mathrm{w}$ tradycji utrwalone ${ }^{45}$, a jego magiczne dokonania Chmielowski opisał też w innych częściach dzieła, relacjonując wznoszenie Świątyni w Jerozolimie. Salomon wsławił się, sprytnie wchodząc w posiadanie pomocnego do prac budowlanych robaka:

robaczka thamur krwią pod liniją rysowano marmury, a te się według linii padały gładko, dlatego młotów, siekier do fabryki nie potrzeba było. Dociekł tej natury robaka mądry Salomon - wsadził w szklaną baniję strusia młodego, stary struś eliberando dziecię swoje przyniósł robaka namienionego z puszczy, krwią dotknął naczynia szklanego i zaraz się rozpadło (II 545).

Oczywiście jest także w Nowych Atenach mowa o innych znanych z Biblii kwestiach magicznych: o pojedynku Mojżesza z magami Faraona, o Saulu i czarownicy z Endor, o Szymonie Magu (III 226-229) - były to typowe treści wykorzystywane w specjalistycznych traktatach o czarach i naukach tajemnych, znanych także w Polsce, na których w rozdziale poświęconym tym kwestiom oparł się Chmielowski.

Bardziej interesujące, bo nie tak jawnie konwencjonalne, są uwagi o innej tradycji tajemnej, właściwej nauce żydowskiej: kabale. Krótka nota o niej znalazła się na końcu omawianego wyżej hasła pt. „Rabini”:

Tuż i cabala (skąd cabalistae) niech swoje pod rabinami ma miejsce, co się wykłada: receptio. Miała w sobie ksiąg 70, które - powiadają - Esdras, syn Sarajasa, najwyższego kapłana żydowskiego, samym mędrcom żydowskim zostawił, aby między lud pospolity nie wyszły. Joannes Picus Mirandula comes (potym książę), bardzo uczony i ciekawy człek, tę kabałę chwali i wiele zebrał z kabalistów dogmatów. Ale teraźniejsza kabała żydowska inna jest, pełna błędów i od Kościoła Bożego wyklęta (III 684).

Notka odsyła do apokryficznej IV Księgi Ezdrasza, gdzie rzeczywiście jest mowa o poleceniu Najwyższego skierowanym do Ezdrasza w sprawie ksiąg, z których część ma pozostać w ukryciu dla wybranych:

${ }_{45}$ Zob. Pablo A. Torijano, Solomon the Esoteric King: From King to Magus, Development of a Tradition, Leiden 2002. 
„siedemdziesiąt zachowasz, aby je przekazać mędrcom z twego ludu"46. Przywołany Pico della Mirandola rzeczywiście zgłębiał wiedzę kabalistyczną, łącząc ją z magią naturalną i koncepcjami czerpanymi z chrześcijaństwa. Najciekawsze tu jest jednak zdanie ostatnie, oceniające nisko „teraźniejszą kabałę”. Czy Chmielowski odnosi się w ten sposób do aktualnych w jego czasach i w jego sąsiedztwie żydowskich ruchów religijnych, opartych przecież także na studiach kabalistycznych? Czy ocenia to duchowe zjawisko? Odpowiedzieć na te pytania można jednoznacznie: nie. Oto bowiem cały ten wywód o kabale, wraz z ostatnim zdaniem, zaczerpnięty został (bez wskazania źródła) z Tirina ${ }^{47}$ - autorem tej krytyki jest uczony jezuita, a pierwotnie dotyczyła ona statusu kabały w XVII w. Oczywiście Chmielowski zapewne tę myśl podzielał, lecz po prostu przejął ją z dobrodziejstwem inwentarza.

Magia opisywana w Biblii lub biblijnych apokryfach ma zupełnie inny status niż czary przypisywane Żydom w Europie przez autorów chrześcijańskich. A istniały przecież jeszcze autentyczne zabiegi magiczne, praktykowane przez Żydów w ramach ich własnej, trudno dostępnej chrześcijanom kultury ludowej ${ }^{48}$. W Nowych Atenach znalazły się pewne o tym informacje w dziale o środkach zaradczych przeciw czarom:

A są-ż jeszcze jakie remedia na czarty i czary?

Odpowiadam, że są, ale niegodziwe, których prawowierni nie mają zażywać katolicy, jeśli chcą uniknąć grzechu i noty: superstitionis; bo te od Kościoła Bożego ani postanowione, ani pochwalone. Jako to Żydzi niewierni noszą przy sobie i na odźwierzach domu swego przybijają tfyttym, niby to relikwiarze, w drzewie, za szkłem pewne słowa, aby wszytkiego złego uchronić się mogli, zamykają; wychodząc $\mathrm{z}$ domu, jak katolicy święconą wodę, tak oni palcem go dotykając a potym palce całując, także na egressie z progu zbroją się przeciw czartom, czarom i wszytkiemu złemu. Powiadają, że tam jest przykazanie Boże napisane i zawarte (III 263-264).

Szczególnie jednak interesowała Chmielowskiego osoba Lilith, której poświęcił aż trzy wpisy z odmiennymi formami żydowskich zaklęć i z odesłaniami do różnych autorów:

464 Ezd 14, 46 (tłum. Stanisław Mędala, [w:] Apokryfy Starego Testamentu, oprac. Ryszard Rubinkiewicz, Warszawa 2000, s. 403).

47 Tirinus, Commentarius in Sacram Scripturam..., t. 2, s. 4 (w osobno paginowanym dziale „Index auctorum”). Wspomniawszy o kabale wychwalanej przez Pica, napisał: „Sed haec non est illa, quam Judaei plenam errorum iam nobis obtrudunt; et damnata est a Sede Apostolica".

${ }^{48}$ Zob. Joshua Trachtenberg, Jewish Magic and Superstition: A Study in Folk Religion, Philadelphia 2004. 
Lilith i Lilis u Hebrajczyków i Żydów jest to Hecate albo Lamia, nocne spectrum albo upierzyca, czyli strzyga, matronom - według ich zdania - nieprzyjazna, dzieci morząca, dusząca. $\mathrm{Z}$ tej racyi w domu położnicy po ścianie piszą Żydzi jako prezerwatywę i antidotum te słowa: Adam Chava, Chutz, Lilith etc. To jest, jako Elijasz rabin i Żydzi, a z nich Jan Achacy Kmita w cytowaniu talmudowych tekstów tłumaczy tym sensem: „Adamie z Ewą przybądź, a Lilis upierzyco precz bądź wyrzucona" (I 39).

Rabbi Szloma albo Salomon twierdzi stulte, że przed uformowaniem Ewy Adam miał żonę Lilis albo Lilith, którą teraz Żydzi mają za nocną ćmę, straszydło, niby upierzycę straszącą i szkodzącą położnicom i dzieciom; stąd piszą w domu położnicy na ścianach w cyrkule te słowa: Adam Chava, chye Lilis, machszayfe, Łoy sechaie; to jest: „Adamie z Ewą przybądź, a Lilis upierzyca niech ustąpi”. Z tej ceremonii Elijasz Theslntes rabin śmieje się jako człek uczony (I 1072).

Jeno zaś Żydówka zlęże, tedy bojąc się czarownicy, którą Żydzi zowią Lilis, Lilith, zaraz piszą na ścianach słowa takie: Adam, Chava, Chutz, Lilith; to jest: „Adamie z Ewą przybądź tu, a ty Lilit - to jest widmo, czarownico - uciekaj”, zaklinając temi słowy czarownice, aby dzieciom świeżo urodzonym i matronom położnicom nic nie szkodziły. A na drzwiach piszą imiona trzech aniołów: Senoi, Sansenoi, Samengeloch, jako świadczy Elijasz Żyd niemiecki w Kircherze (III 264).

Badacze folkloru żydowskiego rzeczywiście znają amulety ochronne z inskrypcjami „Adam hava hutz Lilith” lub imionami aniołów „Senoy, Sansenoy, Semangelof", które służyć mają nowo narodzonym i ich matkom ${ }^{49}$. Chmielowski, przekazując o tym informacje, odsyła do Kmity i Kirchera. Daje przy tej okazji kolejny dowód, że ośmieszające Talmud zestawienia Kmity uważa za równie wiarygodne jak erudycyjne wywody niemieckiego jezuity. W istocie Kmita pobieżnie odniósł się do tej materii ${ }^{50}$; szczegółowe informacje i odesłania zaczerpnął Chmielowski z Kirchera ${ }^{51}$.

49 Zob. hasło Lilith, [w:] Encyclopedia of Jewish Folklore and Traditions, red. Raphael Patai, Haya Bar-Itzhak, Armonk-London 2013, s. 335, 333. Szerzej o tej bohaterce, związanych z nią tradycjach kulturowych, magicznych rytuałach jej odpędzania i zabezpieczających przed nią amuletach zob. Raphael Patai, The Hebrew Goddess, Detroit 1990, s. 221-254 (tu rozdz. „Lilith”). Por. też tenże, Lilith, „The Journal of American Folklore” 77 (1964), nr 306, s. 295-314.

50 Jan Achacy Kmita, Talmud abo wiara żydowska, Kraków 1610, k. A4r: „mówi rabin Slomo: [...] gdy Żydówka w połogu leży, opiszą izbę kredą wokoło z tym napisem: Adam Chawa chuc Lilis, Adamie z Jewą przybądź, a Lilis niech będzie wyrzucona”.

51 Athanasius Kircher, Oedipus Aegyptiacus..., Romae 1652, t. 1, s. 321-322. Ów „Elijasz Żyd niemiecki w Kircherze” występuje w tym dziele jako Elias Levita (hebrajski uczony i poeta, aktywny w Niemczech i Italii w I połowie XVI w.), cytujący rabina Salomona. To właśnie u Kirchera Chmielowski znalazł zestawienie Lilith z Hekate i z Lamią, formułę „Adam, Cheva, Chutz Lilith” oraz imiona trzech aniołów. 


\section{Tematy kontrowersyjne}

W rozdziale pt. „Dubitantius lub kwestyje dotychczas bez responsu”, omawiającym zagadnienia kontrowersyjne, domagające się wyjaśnień, zwłaszcza wobec rozmaitych zdań na ich temat w dziełach różnych autorów, Chmielowski przedstawił wywody ułożone przez siebie, obszerne i ciekawe pod względem formy. Wśród tematów, które mają związki ze sprawami żydowskimi, szczególnie ciekawe są trzy: „O rybie Lewiatan z żydowskich Talmudów”, „O wole Szorobor. Czy jest na świecie?” i „O rzece Sabbaticus zwanej. Czy była albo jest teraz na świecie?” (I 137-140) $)^{52}$.

„Leviathan jest to taka ryba wielka, że cały okrąg świata sobą obtoczywszy trzyma się za swój własny ogon, aby już róść nie mogła. Z tą tedy rybą (powiadają Żydzi) Pan Bóg igra sobie i ją chowa Żydom, po śmierci na potrawy i specyjały dla nich”; „Thalmudistae [...] zostawili Żydom prostym, [...] że się znajduje na świecie wół Szorobor w pustyniach Arabii się pasący takiej wielkości, że z tysiąca gór co dzień trawę zjada, któremu jaskółka lotna dni dwanaście od rogu do rogu leci” ${ }^{53}$. Uwagi o tych olbrzymich stworzeniach oparł Chmielowski na krótkich notkach w książeczce Kmity dotyczącej Talmudu ${ }^{54}$ i stanowczo ich istnienie odrzucił, wzywając czytelnika, by ten wyśmiał „talmudystów naukę”. Natomiast o oddającej cześć Bogu rzece Sabbaticus, „od sabaszu żydowskiego rzeczonej”, która „każdego dnia siódmego, to jest w sobotę, niszczeje i wysycha, innych dni pełna będąc i płynąc" "55, wypowiada się inaczej: uznaje istnienie tej rzeki w dawniejszych czasach, a jej późniejsze zniknięcie wykorzystuje do uwag teologicznych. Istotne jest przy tym, że w sprawie tej rzeki głos zabierali autorzy zgoła inni niż rabini - ci, którym Chmielowski ufa: Pliniusz Starszy, Izydor z Sewilli, Simone Maiolii5, a także Józef Flawiusz ${ }^{57}$.

${ }^{52}$ O tym zob. wydanie krytyczne: Benedykt Chmielowski, Nowe Ateny. Traktat Dubitantius, oprac. Jerzy Kroczak, wstęp Bartosz Marcińczak, Wrocław 2009, s. 100-104 (Bibliotheca Curiosa 3).

53 Tamże, s. 101, 102.

${ }^{54}$ Kmita, Talmud..., k. A2v, Br. Ale o rekreacjach Boga z rybą Lewiatan piszą też inni, przywoływani wyżej autorzy, m.in. Radliński w: Prawda chrześcijańska..., s. 450, 457; Górski, Okazanie kilka btędów..., k. Bv; Sixtus Senensis, Bibliotheca sancta..., s. 200.

${ }_{55}$ Chmielowski, Nowe Ateny. Traktat Dubitantius..., s. 103. Umieszcza ją też w katalogu rzek (I 564), przy czym odsyła do „Dubitantiusa”.

${ }_{56}$ Pliniusz, Naturalis historia XXXI, 24 (pisze, że w Judei rzeka wysycha w każdy szabat); Izydor z Sewilli, Etymologiae XIII, 13, 9 (także lokuje tę rzekę w Judei); Simone Maioli, Dies caniculares..., Ursellis 1600, s. 435.

57 Józef Flawiusz, Wojna żydowska VII, 5, 1. Autor ten przedstawił rzecz odwrotnie: rzeka płynie tylko co siódmy dzień. „Dlatego też nazwano ją Rzeką Sabbatową, które to miano 


\section{Uwagi końcowe}

Niewielu jest autorów żydowskich, których przywoływano na kartach Nowych Aten jako autorytety ${ }^{58}$. Do tych, którzy traktowani są jako wiarygodni i wymieniani najczęściej, należy właśnie Józef Flawiusz, nazywany rozmaicie: „Josephus, historyk żydowski”, „Józef Żydowin”59. Wzmiankowany bywa tam również „Philo Żyd uczony bardzo” (czyli Filon z Aleksandrii), a z nowszych - żyjący ok. 1200 r. rabbi Dawid Kimchi (zapewne dlatego, że cytuje go często Kircher), szerzej omówiony w katalogu rabinów żydowskich (III 682-683). Charakterystyczne jest przy tym, że Chmielowski odwołuje się do opinii tego ostatniego rabina nie bezpośrednio, lecz poprzez chrześcijan, np. pisząc o Molochu, dodaje: „Rabbi Kimchi twierdzi u Autorów, że ten bałwan był ekstraordynaryjnej wielkości” (I 40) - w tym wypadku ci „Autorzy” to właśnie Kircher ${ }^{60}$.

Chmielowski konstruuje zatem swe Nowe Ateny z rozlicznych ksiąg, a zależnie od tematu, od części dzieła, przywoływani z nazwiska bywają różni autorzy. Ale zasadniczo teksty, z których przy szeroko pojętej tematyce żydowskiej naprawdę korzysta, należą przede wszystkim do kręgu erudycyjnego piśmiennictwa epoki wczesnonowożytnej, także do nurtu pism religijnych. Siłą rzeczy odnosi się do takich spraw i tematów, które są ważne dla tych właśnie ksiąg oraz dla ich perspektywy. Poruszając więc zagadnienie nadziei Żydów na przyjście mesjasza, pisze: „wyglądają, nie oglądają, spodziewają się, a nigdy się nie doczekają mesyjasza, [...] mirabilia o nim bają rabinów swoich zwiedzeni bałamuctwem” (I 1069), a dalsze karty wypełnia takimi teologicznymi argumentami zbijającymi opinie rabinów (I 1080-1092), które są właściwe wykorzystywanym przezeń źródłom. O nowszych perturbacjach mesjańskich w świecie żydowskim, o Sabataju Cwi i jego późniejszych zwolennikach nie wspomina - nie było o tym mowy w dziełach, które czytał ${ }^{61}$.

nadano jej od siódmego dnia, który u Żydów jest dniem świętym" (tłum. Jan Radożycki, Warszawa [2007], s. 398).

${ }^{58}$ Oczywiście pomijając autorów ksiąg biblijnych.

${ }^{59}$ Umieścił go nawet w katalogu osób pamięci godnych: „Flavius Josephus, Matatyjasza syn, natione Żyd, sektą faryzeusz, urzędem kapłan żydowski i wódz wojny, od Hieronima ś. Liwijuszem greckim nazwany”. Ujawnił też, dlaczego można go cenić: „Chwali i Chrystusa Pana, iż był cudotwórcą, mąż mądry, i że Go naród żydowski oskarżył i o śmierć przyprowadził" (III 644).

${ }^{60}$ Por. Kircher, Oedipus Aegyptiacus..., t. 1, s. 332-334.

${ }^{61} \mathrm{~W}$ piśmiennictwie chrześcijańskim końca XVII i I połowy XVIII w. nie zajmowano się szerzej sprawami sabatajczyków; prace polskich duchownych dotyczące frankistów uka- 
Autor Nowych Aten w kwestiach żydowskich poruszał się pośród tematów typowych dla tradycyjnej i książkowej wiedzy ${ }^{62}$, co wskazuje też chyba, w jak dużej kulturowej izolacji pozostawali względem niego realnie żyjący Żydzi, ówcześni sąsiedzi ${ }^{63}$. Gdy komentuje aspekty życia duchowego współczesnych mu Żydów, warto podchodzić do takich zapisów ostrożnie, ich aktualność może być bowiem zwodnicza - jak w owym passusie o kabale ${ }^{64}$, w istocie przyswojonym z wiekowej już książki.

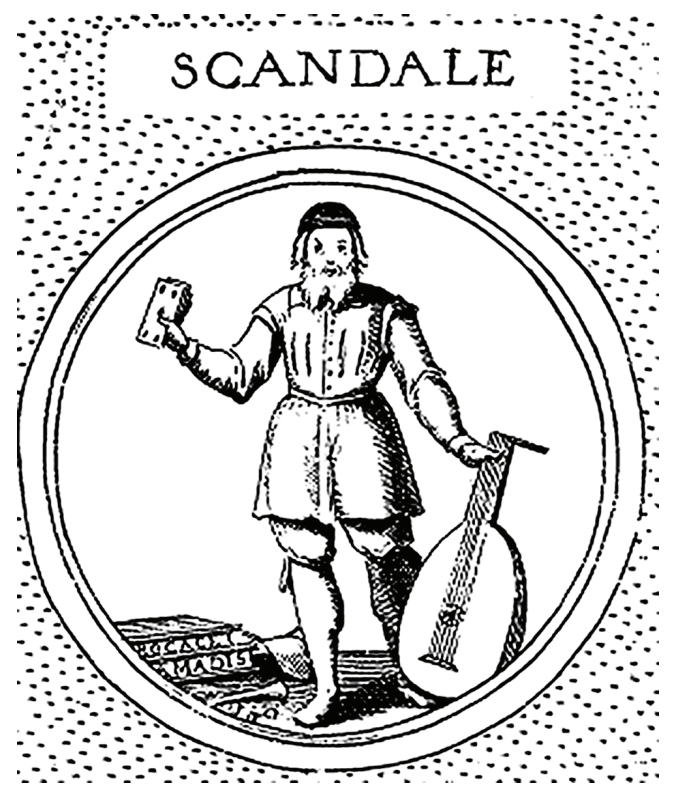

Skandal - rycina we francuskiej wersji Ikonologii Cesare Ripy (cz. 2, Paris 1643). Według Chmielowskiego: „mąż w stroju niby żydowskim”.

zały się już po drugim wydaniu Nowych Aten. Zob. o tym Jan Doktór, Śladami mesjasza-apostaty. Żydowskie ruchy mesjańskie w XVII i XVIII wieku a problem konwersji, Wrocław 1998, s. 24-26.

${ }^{62} \mathrm{O}$ tych typowych wyobrażeniach traktuje klasyczny artykuł: Janusz Tazbir, Żydzi w opinii staropolskiej, [w:] tenże, Świat panów Pasków. Eseje i studia, Łódź 1986, s. 213-241. Zob. też Judith Kalik, Żydowska duchowość, religia i praktyki religijne w oczach Polaków w XVII-XVIII wieku, [w:] Duchowość żydowska w Polsce, red. Michał Galas, Kraków 2000, s. $81-90$.

${ }^{63}$ O symptomach takiej kulturowej izolacji na przykładzie uwag o Żydach w pismach Marcina Bielskiego mówi Dariusz Śnieżko, Mieszanie krwi, „Poznańskie Studia Polonistyczne. Seria Literacka" 22 (2013), s. 20.

${ }^{64}$ „Ale teraźniejsza kabała żydowska inna jest, pełna błędów i od Kościoła Bożego wyklęta” (III 684). 
Można jednak na koniec z dużą pewnością wskazać drobny, ale ciekawy przykład, który jest odbiciem własnych spostrzeżeń dziekana rohatyńskiego i jego doświadczeń ze współczesnymi mu Żydami. W części pt. „Umbry objaśnione”, omawiającej hieroglify, symbole i materiał emblematyczny, tak przedstawił personifikację Skandalu (I 1173), przejętą z francuskiego wydania Ikonologii Cesare Ripy: „Scandalum wyraża mąż w stroju niby żydowskim, w ręku ma karty grackie, w drugiej instrument muzyczny, przy nogach jego leżą księgi z tytułami: Romans a Madis, losy, trąby”65. Słowa: „w stroju niby żydowskim”, są tu dodatkiem Chmielowskiego, jego skojarzeniem wobec ilustracji (w oryginale wcale nie dotyczącej Żydów) zamieszczonej we wspomnianej francuskiej wersji Ripy $^{66}$. Szaty i postać, które na tej rycinie zobaczył, skierowały jego myśli w stronę „starozakonnych” sąsiadów ${ }^{67}$, stanowiąc skromny dowód, że Chmielowski znał Żydów nie tylko z uczonych i pobożnych ksiąg, ale także przynajmniej z widzenia.

Jerzy Kroczak

Uniwersytet Wrocławski jerzy.kroczak@uwr.edu.pl

${ }_{65}$ Zob. wydanie krytyczne: Benedykt Chmielowski, Nowe Ateny. Umbry objaśnione, oprac. Jerzy Kroczak, Jacek Sokolski, wstęp Jacek Sokolski, Wrocław 2015, s. 99 (Bibliotheca Curiosa 28).

${ }^{66}$ O tym: Sokolski, Wstęp, [w:] tamże, s. 39-40. Tu zostało dowiedzione, że Chmielowski używał właśnie wersji francuskiej dzieła Ripy; edycje w innych językach mają odmienne ilustracje.

${ }^{67}$ Choć kwestia strojów używanych przez polskich Żydów w tych czasach nie jest jednoznaczna - zob. o tym Gershon David Hundert, Żydzi w Rzeczypospolitej Obojga Narodów w XVIII wieku. Genealogia nowoczesności, tłum. Marzena Zalewska, Warszawa 2007, s. 121-130. 
